\title{
Phenotypic Diversity of Puccinia helianthi (Sunflower Rust) in the United States from 2011 and 2012
}

Andrew J. Friskop, Department of Plant Pathology, North Dakota State University, Fargo 58102; Thomas J. Gulya, United States Department of Agriculture-Agricultural Research Service Northern Crop Science Laboratory, Fargo, ND 58108; Robert M. Harveson, University of Nebraska, Scottsbluff 69361; Ryan M. Humann, Maricelis Acevedo, and Samuel G. Markell, Department of Plant Pathology, North Dakota State University, Fargo

\begin{abstract}
Friskop, A. J., Gulya, T. J., Harveson, R. M., Humann, R. M., Acevedo, M., and Markell, S. G. 2015. Phenotypic diversity of Puccinia helianthi (sunflower rust) in the United States from 2011 and 2012. Plant Dis. 99:1604-1609.

Puccinia helianthi, causal agent of sunflower rust, is a macrocyclic and autoecious pathogen. Widespread sexual reproduction of $P$. helianthi was documented in North Dakota and Nebraska for the first time in 2008 and has since frequently occurred. Concurrently, an increase in sunflower rust incidence, severity, and subsequent yield loss on sunflower has occurred since 2008. Rust can be managed with resistance genes but determination of virulence phenotypes is important for effective gene deployment and hybrid selection. However, the only $P$. helianthi virulence data available in the United States was generated prior to 2009 and consisted of aggregate virulence phenotypes determined on bulk field collections. The objective of this study was to determine the phenotypic diversity of $P$. helianthi in the United States. $P$. helianthi collections

were made from cultivated, volunteer, and wild Helianthus spp. at 104 locations across seven U.S. states and one Canadian province in 2011 and 2012. Virulence phenotypes of 238 single-pustule isolates were determined on the internationally accepted differential set. In total, 29 races were identified, with races 300 and 304 occurring most frequently in 2011 and races 304 and 324 occurring most frequently in 2012. Differences in race prevalence occurred between survey years and across geography but were similar among host types. Four isolates virulent to all genes in the differential set (race 777) were identified. The resistance genes found in differential lines HA-R3 $\left(\mathrm{R}_{4 b}\right), \mathrm{MC} 29\left(\mathrm{R}_{2}\right.$ and $\left.\mathrm{R}_{10}\right)$, and HA-R2 $\left(\mathrm{R}_{5}\right)$ conferred resistance to $96.6,83.6$, and $78.6 \%$ of the isolates tested, respectively.
\end{abstract}

Sunflower rust, caused by Puccinia helianthi Schwein., occurs on cultivated and volunteer sunflower as well as wild Helianthus spp. (Gulya et al. 1997). P. helianthi is an autoecious and macrocyclic pathogen, and it is presumed that the pathogen is native to North America but occurs globally (Gulya et al. 1997). An increase in sunflower rust incidence and severity has been observed in North Dakota from 2007 to 2009 (Kandel 2012), and data suggest that over 50\% of North Dakota production fields have had at least some level of rust from 2007 to 2011. Yield loss potential is very high, and a near total yield and quality loss was reported in North Dakota in 2008 (Markell et al. 2009). Widespread sexual reproduction events of $P$. helianthi were documented in North Dakota and Nebraska in 2008 (Harveson 2010; Markell et al. 2009).

Rust can be managed with genetic resistance, and several resistance genes have been identified (Qi et al. 2011; Sendall et al. 2006). However, periodic evaluations of rust resistance in sunflower hybrids in the United States indicate that a majority of them are susceptible to the local $P$. helianthi population (Friskop et al. 2011; Gulya and Masirevic 1996; Gulya and Viranyi 1994). For breeding for resistance to be efficient and most effective, the virulence phenotypes of the local pathogen population should be determined. For $P$. helianthi, virulence phenotype is determined on a set of nine internationally accepted differentials (Table 1): susceptible hybrid, MC90, MC29, P386, HA-R1, HA-R2, HA-R3, HA-R4, and HAR5 (Gulya and Masirevic 1996). Differential MC90 contains the $\mathrm{R}_{1}$ gene and differential MC29 has the $\mathrm{R}_{2}$ and $\mathrm{R}_{10}$ genes (Putt and Sackston 1963). Differentials P386, HA-R1, HA-R3, HA-R4, and

Corresponding author: S. Markell; E-mail: samuel.markell@ndsu.edu

*The $\boldsymbol{e}$-Xtra logo stands for "electronic extra" and indicates that five supplementary figures are published online.

Accepted for publication 18 May 2015.

http://dx.doi.org/10.1094/PDIS-11-14-1127-RE

(C) 2015 The American Phytopathological Society
HA-R5 possess alleles of the $\mathrm{R}_{4}$ gene (Miller et al. 1988; Yang et al. 1989). Differential HA-R2 has the $R_{5}$ gene (Miller et al. 1988). Once a virulence phenotype is obtained on a set of differentials, race nomenclature is used to describe the pattern of resistance and susceptibility in the host (Hovmoller et al. 2011). Race nomenclature for sunflower rust uses a numerical triplet coding system, in which differentials are arranged into three sets of three differentials (Gulya and Masirevic 1996). Within each set, virulent reactions are expressed as a discrete value (for example, differential $1=1$, differential $2=2$, and differential $3=4$ ) and an additive value is assigned to each differential triplet (1 through 7 ). Subsequently, the race is expressed as three digits (Gulya and Masirevic 1996).

Phenotypic diversity of a rust pathogen population is often examined in one of two ways. First, virulence phenotypes can be assessed from bulk pathogen collections. This information can be obtained quickly, and can provide a useful snapshot of aggregate virulence in a population. This may be particularly interesting for breeders who are attempting to incorporate resistance to all known races in a region. A second way to examine phenotypic diversity is to determine virulence phenotypes from single-pustule isolates of the pathogen. Single-pustule isolates are clonal, and determination of virulence phenotypes provides information about virulence diversity of individuals within a population and allows scientists to make assessments about virulence combinations within the pathogen. This method is more robust, generates data on the actual diversity of the pathogen population, and has been extensively used in other rust species (Acevedo et al. 2013; Kolmer 1999; Kolmer and Liu 2000; Markell and Milus 2008). Although infrequent surveys of the virulence phenotype of $P$. helianthi from bulk collections have been conducted in the United States (Gulya 2006, 1990; Gulya and Markell 2009; Gulya and Viranyi 1994), virulence diversity using single-pustule isolates has not been done. Survey data from the 1990s and 2000s identified more than two dozen bulk virulence phenotypes (Gulya 2006, 1990; Gulya and Markell 2009; Gulya and Viranyi 1994). However, the number of virulence phenotypes that were present in each bulk sample is not known, nor can the frequency of virulence phenotypes be determined. 
Prior to the 2008 rust survey, completion of the sexual cycle had not been confirmed in North Dakota (Markell et al. 2009), although it is likely that it was occurring but not detected (Putt and Sackston 1963). In 2008, the widespread occurrence of aecia was observed throughout the sunflower-growing areas in Minnesota and North Dakota (Markell et al. 2009). Aecia were found on cultivated, volunteer, and wild Helianthus spp. from early vegetative growth stages until the reproductive stages. Since that initial observation, completion of the sexual cycle (presence of aecia) has been annual and widespread throughout the region (unpublished data). Frequent sexual recombination can lead to the development of new virulence combinations in the pathogen population, may expedite evolution in the pathogen, and may explain the increase in incidence and severity of the disease in the Northern Great Plains (Putt and Sackston 1957; Sendall et al. 2006). A lack of virulence phenotype data obtained from single-pustule isolates during this period of evolution makes determination of pathogen diversity critical. Therefore, the objective of this study was to assess the phenotypic diversity of $P$. helianthi in the United States and Canada from cultivated, volunteer, and wild Helianthus spp.

\section{Materials and Methods}

2011 Pathogen collections. A week-long trip to collect $P$. helianthi samples was completed during the last week of August in North Dakota. The survey route covered approximately $1,600 \mathrm{~km}$ and stops were made periodically at both wild populations and cultivated fields. Specific hybrid information was not available in cultivated fields but visual differentiation between oilseed and confectionary hybrids was made whenever possible. Field-derived singlepustule isolates were collected along a "W" pattern across fields

Table 1. Sunflower rust differential line, resistance genes or alleles, and scoring values for race nomenclature

\begin{tabular}{llcc}
\hline Set & Differential & Resistance gene or alleles & Scoring value $^{\mathbf{a}}$ \\
\hline One & 7350 & $\ldots$ & 1 \\
& MC90 & $\mathrm{R}_{1}$ & 2 \\
\multirow{3}{*}{ Two } & MC29 & $\mathrm{R}_{2}+\mathrm{R}_{10}$ & 4 \\
& P386 & $\mathrm{R}_{4 \mathrm{e}}$ & 1 \\
& HA-R1 & $\mathrm{R}_{4 \mathrm{a}}$ & 2 \\
\multirow{3}{*}{ Three } & HA-R2 & $\mathrm{R}_{5}$ & 4 \\
& HA-R3 & $\mathrm{R}_{4 \mathrm{~b}}$ & 1 \\
& HA-R4 & $\mathrm{R}_{4 \mathrm{c}}$ & 2 \\
& HA-R5 & $\mathrm{R}_{4 \mathrm{~d}}$ & 4
\end{tabular}

a Scoring value is the numerical value associated with virulence on a specific differential. The additive score for each set is the digit in the three-digit race name (Gulya and Masirevic 1996). or stands of wild Helianthus. In all, 2 to 20 single-pustule isolates were obtained from 37 locations.

Multiple leaves with rust uredinia (bulk collection) were obtained from Nebraska and South Dakota. Nine bulk collections from nine discrete locations in Nebraska (Robert Harveson, University of Nebraska-Lincoln Panhandle Research and Extension Center), and one bulk sample from one location in South Dakota (Fabio Pedraza Garcia, Seeds 2000, Breckenridge, MN) were received from collaborators. To obtain single-pustule isolates from bulk collections, bulk samples were inoculated onto 14-day-old plants of the susceptible sunflower hybrid 'Jaguar' (Seeds 2000) in the greenhouse. Approximately 14 days later, urediniospores from individual uredinia were collected separately. Two to three single pustules from each bulk sample were randomly selected to represent diversity at that location. In 2011, in total, 129 single-pustule isolates from 47 locations were obtained for determination of virulence phenotypes (Table 2; Fig. 1).

2012 Pathogen collections. $P$. helianthi samples from wild and cultivated sunflower were obtained during survey trips and from collaborators. Field-derived single-pustule isolates were collected during two rust survey trips in North Dakota, using the same sampling procedures in 2011. The first survey conducted in July covered the northeast and north-central portion of North Dakota, and the second survey trip was conducted in the central and western half of North Dakota. Bulk pathogen collections were received from collaborators in California (Suzanne Latham, California Department of Food and Agriculture and Nick Oliver, Sutter County Department of Agriculture), Manitoba, Canada (Claire Kincaid, National Sunflower Association of Canada), Iowa (Charles Block, United States Department of Agriculture-Agricultural Research Service [USDA-ARS] Plant Introduction Station), Minnesota (Tom Gulya, USDA-ARS Sunflower and Plant Biology Research Unit), Nebraska (Tom Gulya), South Dakota (Tom Gulya), and Texas (Joseph Legako, Triumph Seed Company, Ralls, TX), and single-pustule isolates were generated as previously described. Up to six single-pustule isolates were selected from each location. An additional $P$. helianthi survey trip was conducted in sunflower production areas in Vermont (Heather Darby and Hannah Harwood, University of Vermont) but rust was not detected in any of the 11 fields surveyed. In 2012, in total, 109 single-pustule isolates from 56 locations were obtained for virulence phenotype determination (Table 2; Fig. 1).

Isolate inoculation and urediniospore increase. The susceptible confection hybrid Jaguar (Seeds 2000) was seeded in 7.62-cm conetainers filled with potting soil (Sunshine mix; SunGro Horticulture Distribution Inc., Bellevue, WA). Fourteen days after planting, single-pustule isolates were inoculated onto the first true leaves by suspending urediniospores in Soltrol 170 (ConocoPhillips Inc., Houston) at approximately $2.8 \times 10^{5}$ spores/ml and sprayed onto

Table 2. Puccinia helianthi sampling locations, number of isolates collected, and number of races identified from sunflower host types and geographic locations in 2011 and $2012^{\mathrm{a}}$

\begin{tabular}{|c|c|c|c|c|c|c|c|c|c|c|c|c|c|}
\hline \multirow[b]{2}{*}{ Host } & \multirow[b]{2}{*}{ Number of ${ }^{\mathbf{b}}$} & \multicolumn{3}{|c|}{2011} & \multicolumn{8}{|c|}{2012} & \multirow[b]{2}{*}{ Tota } \\
\hline & & $\overline{\mathrm{NE}}$ & ND & $\overline{\text { SD }}$ & $\overline{\mathbf{C A}}$ & IA & MN & $\mathbf{N E}$ & ND & SD & TX & $\overline{\mathrm{MB}}$ & \\
\hline \multirow[t]{3}{*}{ Oil } & Locations & 0 & 27 & 0 & 0 & 0 & 0 & 0 & 9 & 0 & 0 & 0 & 36 \\
\hline & Isolates & 0 & 79 & 0 & 0 & 0 & 0 & 0 & 29 & 0 & 0 & 0 & 108 \\
\hline & Races & 0 & 13 & 0 & 0 & 0 & 0 & 0 & 12 & 0 & 0 & 0 & 19 \\
\hline \multirow[t]{3}{*}{ Confection } & Locations & 0 & 4 & 1 & 0 & 0 & 2 & 0 & 6 & 0 & 0 & 2 & 16 \\
\hline & Isolates & 0 & 12 & 3 & 0 & 0 & 6 & 0 & 19 & 0 & 0 & 3 & 43 \\
\hline & Races & 0 & 6 & 2 & 0 & 0 & 3 & 0 & 10 & 0 & 0 & 2 & 13 \\
\hline \multirow[t]{3}{*}{ Wild } & Locations & 0 & 5 & 0 & 0 & 3 & 2 & 2 & 2 & 0 & 0 & 0 & 14 \\
\hline & Isolates & 0 & 13 & 0 & 0 & 5 & 4 & 3 & 2 & 0 & 0 & 0 & 27 \\
\hline & Races & 0 & 7 & 0 & 0 & 3 & 3 & 3 & 1 & 0 & 0 & 0 & 12 \\
\hline \multirow[t]{3}{*}{ Unknown cultivated } & Locations & 9 & 1 & 0 & 7 & 0 & 5 & 4 & 3 & 7 & 1 & 1 & 38 \\
\hline & Isolates & 20 & 2 & 0 & 9 & 0 & 8 & 5 & 4 & 9 & 2 & 1 & 60 \\
\hline & Races & 6 & 2 & 0 & 6 & 0 & 7 & 4 & 4 & 7 & 2 & 1 & 22 \\
\hline
\end{tabular}

\footnotetext{
a Abbreviations: $\mathrm{NE}=$ Nebraska, $\mathrm{ND}=$ North Dakota, $\mathrm{SD}=$ South Dakota, $\mathrm{CA}=$ California, $\mathrm{IA}=\mathrm{Iowa}, \mathrm{MN}=\mathrm{Minnesota}, \mathrm{TX}=\mathrm{Texas}$, and MB = Manitoba $(\mathrm{Canada})$

${ }^{\mathrm{b}}$ Locations $=$ number of locations from which $P$. helianthi isolates were collected, with respect to host-type and state; Isolates $=$ number of $P$. helianthi isolates collected, with respect to host-type and state; and Races = number of races detected according to virulence phenotypes of $P$. helianthi isolates, with respect to host type and state.
} 
susceptible plants. To prevent cross contamination, all plants were inoculated in a chemical hood with negative air pressure. Between each inoculation, the hood was sprayed down with acetone and allowed to dry. The oil suspension was allowed to dry on the plants for 30 to $40 \mathrm{~min}$; then, plants were placed into misting chambers for 18 to $20 \mathrm{~h}$ at $22 \pm 2^{\circ} \mathrm{C}$ with a photoperiod of $16 \mathrm{~h}$, then moved to isolation chambers in a greenhouse at $22 \pm 2^{\circ} \mathrm{C}$ with a photoperiod of $16 \mathrm{~h}$. Light was supplemented by a 400-W halogen bulb (Phillips, Royal Philips of The Netherlands) using the P. L. Light Systems (model PL2000 HPS Super; P. L. Light Systems, Beamsville, ON, Canada). Urediniospore collections were made 14, 16, and 18 days after inoculation. Collected urediniospores were used to inoculate differentials or desiccated and stored temporarily in a refrigerator $\left(4^{\circ} \mathrm{C}\right)$ or placed in long-term storage in a cryofreezer at $-80^{\circ} \mathrm{C}$ ).

Virulence phenotype evaluation. To evaluate virulence phenotypes, each isolate was inoculated onto three plants of each of the nine internationally accepted differentials, and repeated once. Differentials were planted in 4-by-9 cell packs (T \& O Plastics, St. Paul, $\mathrm{MN}$ ) using Sunshine mix as a growth medium. Plants were grown in a greenhouse with diurnal temperatures of 24 and $20^{\circ} \mathrm{C}$ with a 16-h photoperiod. After 14 days, fresh urediniospores were inoculated on the first set of true leaves using methods described above. Infection type (IT) was evaluated 13 to 15 days postinoculation using a modified 0-to-5 scale from Yang et al. (1986), where $0=$ immune, $;=$ flecks, $1=$ pustules smaller than $0.2 \mathrm{~mm}, 2=$ pustules of 0.2 to $0.4 \mathrm{~mm}, 3=0.4$ to $0.6 \mathrm{~mm}, 4=0.6$ to $0.8 \mathrm{~mm}$, and 5 = pustules larger than $0.8 \mathrm{~mm}$. An IT of 3 or greater was considered to be a susceptible reaction.

\section{Results}

2011 Pathogen collections. Seventeen races were detected from the 129 single-pustule isolates tested. Races 300 and 304 were the most commonly detected, comprising $69.7 \%$ of the tested isolates (Table 3). The least virulent race detected was race 300, which conferred virulence to only two of the nine differentials (including the susceptible). The most virulent race detected was 776 , which was virulent on eight of the nine differentials. Race 776 was detected only once in 2011, originating from a north-central confectionary field in North Dakota. Multiple races were identified from approximately $77 \%$ of the locations sampled. For example, three races were characterized from three isolates at 10 locations in North Dakota and 1 location in Nebraska. Few race differences existed on different sunflower host types. Race 736 was the only race identified from a wild population that was not identified from cultivated sunflower, whereas race 776 was only detected on a confection hybrid. Numerous races were detected from oil hybrids that were not represented in either confection hybrids or wild hosts.

Resistance gene $\mathrm{R}_{4 \mathrm{~b}}$, found in the differential line HA-R3, conferred resistance to $98.4 \%$ of the isolates evaluated in 2011 (Table 4). Resistance genes $\mathrm{R}_{2}$ and $\mathrm{R}_{10}$, found in differential line MC29, and $\mathrm{R}_{5}$, found in HA-R2, conferred resistance to 96.9 and $89.9 \%$ of the isolates, respectively. The resistance gene $\mathrm{R}_{1}$ did not confer resistance to any of the isolates tested, and resistance gene $\mathrm{R}_{4 \mathrm{~d}}$ conferred resistance to only $48.8 \%$ of the isolates.

2012 Pathogen collections. In total, 27 races were detected from 109 single-pustule isolates evaluated in 2012. The most common race detected was 304 , which was found in five of the seven states sampled and comprised over $18 \%$ of the total collection (Table 3 ). Races 324, 364, and 704 were detected in 10.1, 7.3, and 7.3\% of the isolates tested, respectively. The least virulent race detected was 300 . The most virulent race detected was 777 , which was virulent on all nine differentials. Race 777 was detected at two locations in Nebraska, one location in North Dakota, and one location in Manitoba, Canada.

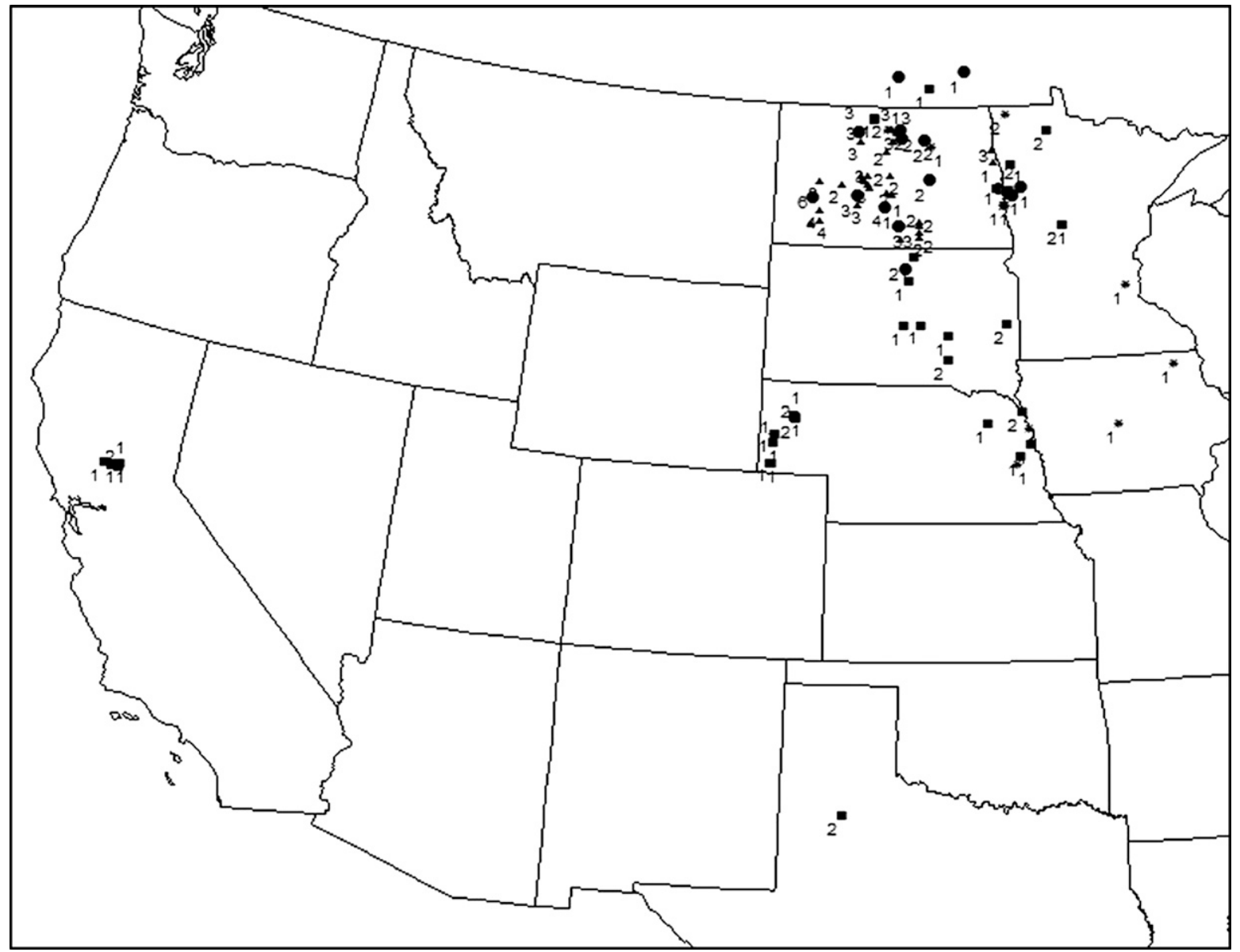

Fig. 1. Location, host type (circle = cultivated confectionary, triangle = cultivated oilseed, square = cultivated unknown, and star $=$ wild), and number of Puccinia helianthi races (number) identified in each sampling location in 2011 and 2012. 
The resistance gene $\mathrm{R}_{4 \mathrm{~b}}$, found in differential line HA-R3, conferred resistance to $94.5 \%$ of the isolates tested (Table 4). Resistance genes $R_{2}$ and $R_{10}$, found in differential line $M C 29$, and $R_{5}$, found in HA-R2, conferred resistance to 68.3 and $65.1 \%$ of the tested isolates, respectively. Resistance genes $\mathrm{R} 4_{\mathrm{d}}$ and $\mathrm{R} 4_{\mathrm{a}}$, found in lines HA-R5 and HA-R1, conferred resistance to only 7.3 and $50.5 \%$ of the tested isolates, respectively. Multiple races were recovered in $81 \%$ of the sampling locations. At one location, six different races were detected from six different isolates (ND12_18).

Virulence phenotypes across year, host, and geographic location. In total, 29 races were detected collectively in 2011 and 2012 (Table 3). In all, 2 P. helianthi races detected in 2011 were not detected in 2012, while 12 races detected in 2012 were not detected in 2011 (Table 3). Race 304 was the most common race identified in both years, followed by race 300 in 2011 and race 324 in 2012. Race 300 was found only
$2.8 \%$ of the time in 2012 and race 324 was found only $2.3 \%$ of the time in 2011 .

All isolates used in this study were virulent on differentials 7350 and MC90 (Table 4), and limited variation of virulence among states and hosts were found. Virulence to all differentials was found in pathogen collections from Nebraska, North Dakota, and Manitoba, while isolates from Iowa conferred virulence to only five differentials (Table 4). Detection frequency of virulence on differentials was similar among host type (Table 4 ). Resistance gene $\mathrm{R}_{4 \mathrm{~b}}$ most frequently provided resistance to all isolates tested, regardless of geography or host (Table 4)

\section{Discussion}

To the best of our knowledge, this is the first race survey done with single-pustule isolates of $P$. helianthi in the United States. Over 2 years, 29 races were identified on three sunflower host types across

Table 3. Number and frequency of Puccinia helianthi races detected in 2011 and 2012

\begin{tabular}{|c|c|c|c|c|c|c|c|}
\hline \multirow[b]{2}{*}{ Race } & \multirow[b]{2}{*}{ Virulence phenotype } & \multicolumn{2}{|c|}{2011} & \multicolumn{2}{|c|}{2012} & \multicolumn{2}{|c|}{ Total } \\
\hline & & $n$ & $\%$ & $n$ & $\%$ & $n$ & $\%$ \\
\hline 300 & 7350, МC90 & 49 & 38.0 & 3 & 2.8 & 52 & 21.8 \\
\hline 304 & 7350, MC90, HA-R5 & 41 & 31.8 & 20 & 18.3 & 61 & 25.6 \\
\hline 320 & 7350, MC90, HA-R1 & 2 & 1.6 & 1 & 0.9 & 3 & 1.3 \\
\hline 322 & 7350, MC90, HA-R1, HA-R4 & 1 & 0.8 & 0 & 0 & 1 & 0.4 \\
\hline 324 & 7350, MC90, HA-R1, HA-R5 & 3 & 2.3 & 11 & 10.1 & 14 & 5.9 \\
\hline 326 & 7350, MC90, HA-R1, HA-R4 HA-R5 & 1 & 0.8 & 1 & 0.9 & 2 & 0.8 \\
\hline 330 & 7350, MC90, P386, HA-R1 & 1 & 0.8 & 1 & 0.9 & 2 & 0.8 \\
\hline 332 & 7350, MC90, P386, HA-R1, HA-R4 & 7 & 5.4 & 1 & 0.9 & 8 & 3.4 \\
\hline 334 & 7350, MC90, P386, HA-R1, HA-R5 & 0 & 0 & 4 & 3.7 & 4 & 1.7 \\
\hline 336 & 7350, MC90, P386, HA-R1, HA-R4, HA-R5 & 6 & 4.7 & 7 & 6.4 & 13 & 5.5 \\
\hline 337 & 7350, MC90, P386, HA-R1, HA-R3, HA-R4, HA-R5 & 2 & 1.6 & 1 & 0.9 & 3 & 1.3 \\
\hline 340 & 7350, MC90, HA-R2 & 2 & 1.6 & 1 & 0.9 & 3 & 1.3 \\
\hline 344 & 7350, MC90, HA-R2, HA-R5 & 9 & 7.0 & 7 & 6.4 & 16 & 6.7 \\
\hline 364 & 7350, MC90, HA-R1, HA-R2, HA-R5 & 0 & 0 & 8 & 7.3 & 8 & 3.4 \\
\hline 366 & 7350, MC90, HA-R1, HA-R2, HA-R4, HA-R5 & 0 & 0 & 3 & 2.8 & 3 & 1.3 \\
\hline 372 & 7350, MC90, P386, HA-R1, HA-R2, HA-R4 & 1 & 0.8 & 0 & 0 & 1 & 0.4 \\
\hline 374 & 7350, MC90, P386, HA-R1, HA-R2, HA-R5 & 0 & 0 & 1 & 0.9 & 1 & 0.4 \\
\hline 376 & 7350, MC90, P386, HA-R1, HA-R2, HA-R4, HA-R5 & 0 & 0 & 5 & 4.6 & 5 & 2.1 \\
\hline 704 & 7350, MC90, MC29, HA-R5 & 1 & 0.8 & 8 & 7.3 & 9 & 3.8 \\
\hline 724 & 7350, MC90, MC29, HA-R1, HA-R5 & 0 & 0 & 2 & 1.8 & 2 & 0.8 \\
\hline 726 & 7350, MC90, MC29, HA-R1, HA-R4, HA-R5 & 0 & 0 & 1 & 0.9 & 1 & 0.4 \\
\hline 732 & 7350, MC90, MC29, P386, HA-R1, HA-R4 & 0 & 0 & 1 & 0.9 & 1 & 0.4 \\
\hline 734 & 7350, MC90, MC29, P386, HA-R1, HA-R5 & 1 & 0.8 & 1 & 0.9 & 2 & 0.8 \\
\hline 736 & 7350, MC90, MC29, P386, HA-R1, HA-R4, HA-R5 & 1 & 0.8 & 7 & 6.4 & 8 & 3.4 \\
\hline 737 & 7350, MC90, MC29, P386, HA-R1, HA-R3, HA-R4, HA-R5 & 0 & 0 & 1 & 0.9 & 1 & 0.4 \\
\hline 744 & 7350, MC90, MC29, HA-R2, HA-R5 & 0 & 0 & 1 & 0.9 & 1 & 0.4 \\
\hline 764 & 7350, MC90, MC29, HA-R1, HA-R2, HA-R5 & 0 & 0 & 1 & 0.9 & 1 & 0.4 \\
\hline 776 & 7350, MC90, MC29, P386, HA-R1, HA-R2, HA-R4, HA-R5 & 1 & 0.8 & 7 & 6.4 & 8 & 3.4 \\
\hline 777 & 7350, MC90, MC29, P386, HA-R1, HA-R2, HA-R3, HA-R4, HA-R5 & 0 & 0 & 4 & 3.7 & 4 & 1.7 \\
\hline Total & & 129 & & 109 & & 238 & \\
\hline
\end{tabular}

Table 4. Number and frequency of isolates virulent on each of the nine internationally accepted differentials (Diff.), by state ${ }^{\mathrm{a}}$

\begin{tabular}{|c|c|c|c|c|c|c|c|c|c|c|c|c|c|}
\hline \multirow[b]{3}{*}{ Diff. } & \multicolumn{4}{|c|}{2011} & \multicolumn{9}{|c|}{2012} \\
\hline & $\mathbf{N E}$ & ND & SD & Total & $\mathrm{CA}$ & IA & MN & NE & ND & SD & TX & MB & Total \\
\hline & $n(\%)$ & $n(\%)$ & $n(\%)$ & $n(\%)$ & $n(\%)$ & $n(\%)$ & $n(\%)$ & $n(\%)$ & $n(\%)$ & $n(\%)$ & $n(\%)$ & $n(\%)$ & $n(\%)$ \\
\hline 7350 & $20(100)$ & $106(100)$ & $3(100)$ & $129(100)$ & $9(100)$ & $5(100)$ & $18(100)$ & $8(100)$ & $54(100)$ & $9(100)$ & $2(100)$ & $4(100)$ & 109 (100) \\
\hline MC90 & $20(100)$ & $106(100)$ & $3(100)$ & $129(100)$ & $9(100)$ & $5(100)$ & $18(100)$ & $8(100)$ & $54(100)$ & $9(100)$ & $2(100)$ & $4(100)$ & 109 (100) \\
\hline MC29 & $0(0)$ & $5(4.7)$ & $0(0)$ & $5(3.8)$ & $7(77.8)$ & $2(40)$ & $6(33.3)$ & $5(62.5)$ & $10(18.5)$ & $3(33.3)$ & $0(0)$ & $1(25)$ & $34(31.2)$ \\
\hline P386 & $6(30)$ & $14(13.2)$ & $0(0)$ & $20(15.5)$ & $7(77.8)$ & $0(0)$ & 7 (38.9) & $3(37.5)$ & $17(31.5)$ & $4(44.4)$ & $2(100)$ & $1(25)$ & 41 (37.6) \\
\hline HA-R1 & $6(30)$ & $21(19.8)$ & $0(0)$ & $27(20.9)$ & $8(88.9)$ & $1(20)$ & $11(61.1)$ & $4(50)$ & $33(61.1)$ & $7(77.8)$ & $2(100)$ & $3(75)$ & $69(63.3)$ \\
\hline HA-R2 & $1(5)$ & $12(11.3)$ & $0(0)$ & $13(10.1)$ & $5(55.6)$ & $0(0)$ & $4(22.2)$ & $2(25)$ & $26(48.1)$ & $0(0)$ & $0(0)$ & $1(25)$ & $38(21.4)$ \\
\hline HA-R3 & $0(0)$ & $2(1.9)$ & $0(0)$ & 2 (1.6) & $1(11.1)$ & $0(0)$ & $0(0)$ & $2(25)$ & $1(1.9)$ & $1(11.1)$ & $0(0)$ & $1(25)$ & $8(3.4)$ \\
\hline HA-R4 & $5(25)$ & $15(14.2)$ & $0(0)$ & $20(15.5)$ & $6(66.7)$ & $0(0)$ & $5(27.8)$ & $4(50)$ & $19(35.2)$ & $3(33.3)$ & $1(50)$ & $1(25)$ & $59(24.8)$ \\
\hline HA-R5 & $4(20)$ & $61(57.5)$ & $1(33.3)$ & $66(51.2)$ & $9(100)$ & $4(80)$ & $16(88.9)$ & $6(75)$ & $54(100)$ & $8(88.9)$ & $0(0)$ & $4(100)$ & $167(70.2)$ \\
\hline Total & 20 & 106 & 3 & 129 & 9 & 5 & 18 & 8 & 54 & 9 & 2 & 4 & 238 \\
\hline
\end{tabular}

a Abbreviations: NE = Nebraska, ND = North Dakota, $\mathrm{SD}=$ South Dakota, $\mathrm{CA}=$ California, $\mathrm{IA}=\mathrm{Iowa}, \mathrm{MN}=\mathrm{Minnesota}, \mathrm{TX}=\mathrm{Texas}$, and $\mathrm{MB}=\mathrm{Manitoba}$ (Canada). 
seven U.S. states and one Canadian province. The number of races detected in 2012 was higher than in 2011, and frequency of the races identified varied between years. For example, 17 races were identified in 2011 and approximately 32 and $38 \%$ of the isolates collected were races 300 and 304, respectively. However, 27 races were identified in 2012 and approximately 3 and $18 \%$ of isolates collected were races 300 and 304, respectively. Similarly, 30 isolates were identified as races $364,704,736$, or 776 in 2012, whereas only 3 isolates were identified as any of these races in 2011. The race prevalence differences between years could be explained, in part, by the expansion of sampling areas in 2012. In 2011, the sampling area was limited to the three Northern Great Plains states of North Dakota, South Dakota, and Nebraska whereas, in 2012, the sampling area expanded into California, Iowa, Manitoba (Canada), Minnesota, and Texas.

Although a limited number of isolates were collected from most states, isolates from California generally appeared to be virulent on more differentials than isolates collected from other states. Most cultivated sunflower fields in California are used for seed production and have a diverse number of host genotypes and resistant genes in a small production area. Carson (2009) demonstrated that this situation may facilitate the selection of additional and complex virulence phenotypes in P. coronata f. sp. avenae (Carson 2009). A better understanding of virulence in California seed production fields could provide useful phenotypic information for production fields in the upper Midwest.

No salient differences in virulence were found among wild $\mathrm{Hel}$ ianthus spp., cultivated confectionary sunflower, and cultivated oil sunflower. Out of the 108, 43 and 27 isolates collected from oil, confection, and wild Helianthus spp., 19, 13, and 12 different races were identified, respectively. Additionally, only two races (726 and 732, identified in Minnesota and Nebraska, respectively) were identified on a wild Helianthus sp. that were not found on cultivated sunflower types. The consistency of races identified among host types is likely a result of the coexistence of wild Helianthus spp. and cultivated sunflower. Natural stands of wild sunflower can be easily found in most field ditches, farmsteads, and preserved lands (such as U.S. National Grasslands and State Parks) and are planted in towns by many home gardeners (Berglund 2007), particularly in the U.S. Great Plains, where most cultivated sunflower crops are grown.

Approximately two-thirds of the isolates tested in this study originated from North Dakota. Even though 21 races were detected collectively in North Dakota, only 8 races $(304,324,326,336,344,704$, 736 , and 776) were found in both years. Thirty-five isolates originating from North Dakota were characterized as race 300 in 2011, yet the race was not detected in 2012. Although changes in deployed host resistance can facilitate widespread race changes, to the best of our knowledge, a shift in deployed resistance (for example, new resistance genes or more widespread use of resistance) did not occur in 2011 and 2012. One possible explanation for the differences in race prevalence could be due to differences in sampling. Because the locations sampled were determined in response to reported outbreaks of rust, the time and location of sampling differed between the years. In 2011 , isolates were collected from the central and north-central portions of the state whereas, in 2012, isolates were collected from the west and southwest part of the state. No location sampled in 2011 was sampled again in 2012, due to crop rotation and the destruction of wild populations. In 2011, a sunflower rust epidemic occurred in North Dakota, and all isolates were collected at the end of July. However, in 2012, incidence and severity of sunflower rust remained low throughout the growing season, and only a limited number of isolates could be collected sporadically in July; therefore, isolates were collected again in September. It is also possible that differences in race prevalence were not necessarily due to the time and location of sampling but, rather, to the differences in rust incidence and severity between the 2 years. Another possibility is that the very high level of rust incidence and severity in 2011 may have been followed by a high level of sexual recombination in 2012 and, consequently, different races were detected in 2012 even though incidence and severity remained low throughout the season.
The majority of $P$. helianthi isolates tested in the study were avirulent on HA-R3 $\left(\mathrm{R}_{4 \mathrm{~b}}\right)$, which is overwhelmingly more effective than the other $\mathrm{R}_{4}$ alleles present in the lines P386, HA-R1, HA-R4, and HA-R5. The genes in MC29 $\left(R_{2}+R_{10}\right)$ and HA-R2 $\left(R_{5}\right)$, conferred resistance to 83.6 and $78.6 \%$ of the isolates tested, respectively. Consequently, the $R_{2}, R_{4 b}, R_{5}$, and $R_{10}$ genes were most effective against the pathogen, and pyramiding any combination of them may be valuable for disease management in the United States. However, these genes may not necessarily be the most effective in other countries. For example, although the genes in MC29 were effective against the vast majority of isolates characterized in the United States, Moreno et al. (2011) characterized 17 isolates in Argentina and found that all of them were virulent on MC29 $\left(R_{2}+R_{10}\right)$. Similarly, Jing et al. (2015) conducted a $P$. helianthi survey with 44 isolates in China and determined that $18 \%$ of the isolates were virulent on HA-R3 $\left(\mathrm{R}_{4 \mathrm{~b}}\right)$ whereas, in this study, approximately $3 \%$ of the isolates were virulent on HA-R3.

The center of origin of Helianthus spp. and P. helianthi is thought to be in the United States; therefore, it is likely that a higher level of genetic diversity in the pathogen exists in North America than in other regions where sunflower crops are produced. Direct comparisons of race diversity among continents is difficult due to differences in the differentials used, the number of isolates characterized, and the techniques used to assess virulence phenotypes. For example, when considering only the same differential lines used in our study, only six races were reported from Argentina (Moreno et al. 2011). However, only 17 pathogen isolates were characterized in Argentina and the presence of any uredina was coded as virulent (IT $=1$ to 5 ) whereas, in the current study, we coded IT higher than 3 as virulent. In Australia, 16 pathotypes were reported from isolates collected over an 11-year period (Kong et al. 1999). However, the pathotypes were determined on a differential set consisting of eight of the nine lines used in our study (all but MC90), two lines with the same gene were used in place of MC90, and 12 additional lines, many of which are proprietary lines and some with an unknown source of resistance. If data from the 12 additional lines are excluded, only 11 pathotypes would have been identified (coding to races 300, 324, 325, 327, 334, 337, 360, 724, 727, 736, and 737). In China, Jing et al. (2015) evaluated the virulence phenotypes of 44 isolates using the same differential lines and techniques as the current study, and reported only six races.

Although this article presents the first virulence phenotype diversity data for the U.S. Great Plains from a collection of $P$. helianthi single-pustule isolates, previous surveys were done using bulk $P$. helianthi collections. Gulya and Markell (2009) evaluated 284 bulk collections on the $P$. helianthi differential set and found that nearly $50 \%$ of the virulence phenotypes coded as races 334 and 336. In the current study, the prevalence of these specific races was very low but multiple races were frequently identified in the same field (Fig. 1), consistent with conclusions that phenotypic richness of autoecious and macrocyclic pathogens can be very high within a field (Jochua et al. 2008). Although different methods were used in the two studies, the comparison of their results circumstantially supports the idea that virulence phenotypes of bulk collections may confer virulence to more differentials than individual single-pustule isolates. Results of the these two studies were similar in that genes found in CM29, HAR2, and HAR3 were most likely to confer resistance to the $P$. helianthi population in the Northern Great Plains, and Gulya and Markell (2009) were able to reach those conclusions without the labor involved in generating and increasing single-pustule isolates.

However, conclusions that can be made from virulence phenotype information using only bulk collections is limited or may be misleading in several important ways. First, phenotypic data from bulk collections provides no mechanism to assess phenotypic or genotypic frequency among individuals. This makes comparisons among populations over time or geographic locations very difficult. Furthermore, the ability to precisely monitor any specific virulence distribution or changes within a population does not exist. Second, the virulence phenotype from bulk collections may be inconsistent because of the diverse phenotypes among individuals within each 
collection. This could reduce the reliability of the data if bulk collections are reevaluated later. This is particularly important in rust pathosystems because pathogen collections are often revisited as new differential lines are added. Third, because virulence data from bulk collections may overestimate the actual virulence frequency present in an entire pathogen population (as is likely the case in the $P$. helianthi pathosystem), unintended negative decisions could be made when breeding for resistance. For example, if one host genotype contains a gene conferring resistance to $99 \%$ of the isolates present in a field but is susceptible to the bulk collection it is screened against, that potentially useful genotype (and gene) may be discarded. Alternately, if isolates of multiple races within a bulk collection have differing levels of aggressiveness, it is possible that the bulk collection will "lose virulence" over time. This could infer that a genotype is resistant to a bulk "race" when it is actually susceptible, and a decision to keep the genotype in a breeding program could occur when the desired outcome was that it be discarded. Although the use of bulk collections may provide a faster mechanism to screen germplasm for resistance, the limitation and risks of those results need to be recognized.

Since the time of this study, several additional resistance genes have been identified, including $\mathrm{R}_{11}, \mathrm{R}_{12}$, and alleles of the $\mathrm{R}_{13}$ gene (Bulos et al. 2013; Gong et al. 2013a, b; Qi et al. 2011, 2012), To date, none of these recently identified genes have been incorporated into an accepted differential set and, because this work began before the identification of these genes and their availability in germplasm, these genes and lines were not included in this study. To the best of our knowledge, these resistance genes have not yet been incorporated into any commercially available U.S. hybrids. The expansion of the differential set in the near future will be critical for accurate assessment of $P$. helianthi diversity. Already, Moreno et al. (2011) reported that one race isolate (race 700) from Argentina confers virulence on HAR-6, a line that has been reported to be resistant to even the most virulent race, 777. Moreno proposes this race be named "7001" and suggests increasing the differentials in the internationally accepted differential set. We support the inclusion of HAR-6 $\left(\mathrm{R}_{13 \mathrm{a}}\right)$ into the differential set as suggested by Moreno et al. (2011), and further suggest that Rf ANN-1742 $\left(\mathrm{R}_{11}\right)$ and RHA $464\left(\mathrm{R}_{12}\right)$ also be included into an expanded differential set.

\section{Acknowledgments}

We thank C. Block, H. Darby, F. Pedraza Garcia, H. Harwood, C. Kincaid, S. Latham, J. Legako, and N. Oliver for P. helianthi samples; J. Nowatzki for map creation; and the National Sunflower Association, the North Dakota State Board of Agricultural Research and Education, and the North Dakota State University Agricultural Experiment station for funding.

\section{Literature Cited}

Acevedo, M., Steadman, J., and Rosas, J. C. 2013. Uromyces appendiculatus in Honduras: Pathogen diversity and host resistance screening. Plant Dis. 97:652-661.

Berglund, D. 2007. Introduction. In: Sunflower Production Guide. North Dakota State University Extension Publication A-1331.

Bulos, M., Ramos, M. L., Altieri, E., and Sala, C. 2013. Molecular mapping of a sunflower rust resistance gene from HAR6. Breed. Sci. 63:141-146.

Carson, M. L. 2009. Crown rust development and selection for virulence in Puccinia coronata f. sp. avenae in an oat multiline cultivar. Plant Dis. 93:347-353.

Friskop, A.J, Schatz, B., Mathew, F., Hendrickson, P., Gulya, T., and Markell, S. 2011. Sunflower hybrid susceptibility and the impact on yield to sunflower rust in North Dakota. (Abstr.) Phytopathology 101:S2.2.

Gong, L., Gulya, T. J., Markell, S. G., Hulke, B. S., and Qi, L. L. 2013a. Genetic mapping of rust resistance genes in confection sunflower line HA-R6 and oilseed line RHA 397. Theor. Appl. Genet. 126:2039-2049.

Gong, L., Hulke, B. S., Gulya, T. J., Markell, S. G., and Qi, L. L. 2013b. Molecular tagging of a novel rust resistance gene $R_{12}$ in sunflower (Helianthus annuus L.). Theor. Appl. Genet. 126:93-99.

Gulya, T., Rashid, K., and Masirevic, S. 1997. Sunflower diseases. Pages 263-377 in: Sunflower Technology and Production. A. A. Schneiter, ed. American Society Agronomy, Madison, WI.

Gulya, T. J. 1990. The sunflower rust situation in 1989. In: Proc. 12th Sunflower Res. Workshop. National Sunflower Association, Bismarck, ND.
Gulya, T. J. 2006. The sunflower rust situation: Current races in the northern and central Great Plains and resistance in oilseed and confection hybrids. Proc. 28th Sunflower Res. Workshop. Online publication. National Sunflower Association, Bismarck, ND.

Gulya, T. J., and Markell, S. 2009. Sunflower rust status-2008: Race frequency across the Midwest resistance among commercial hybrids. Proc. 31st Sunflower Research Workshop. Online publication. National Sunflower Association, Bismarck, ND. http://www.sunflowernsa.com/uploads/resources/76/gulya_ruststatus_09.pdf

Gulya, T. J., and Masirevic, S. 1996. Inoculation and evaluation methods for sunflower rust. Pages 263-379 in: Proc. 18th Sunflower Research Workshop. National Sunflower Association, Bismarck, ND.

Gulya, T. J., and Viranyi, F. 1994. Virulent new races of sunflower rust (Puccinia helianthi) from the southern Great Plains. Pages 31-38 in: Proc. 16th Sunflower Research Workshop. National Sunflower Association, Bismarck, ND

Harveson, R. 2010. First report of early spore stages of sunflower rust, caused by Puccinia helianthi, in Nebraska. Online publication. Plant Health Prog. doi: 10.1094/PHP-2010-0315-01-BR

Hovmoller, M. S., Sorensen, C. K., Walter, S., and Justesen, A. F. 2011. Diversity of Puccinia striiformis on cereals and grasses. Annu. Rev. Phytopathol. 49: 197-217.

Jing, L., Xu, X., Jing, J., Li, L., and Navi, S. 2015. Determination of physiological races and evaluation of sunflower for resistance to Puccinia helianthi Schw. J. Phytopathol. 163:507-512.

Jochua, C., Amane, M. I. V., Steadman, J. R., Xue, X., and Eskridge, K. M. 2008 Virulence diversity of the common bean rust pathogen within and among individual bean fields and development of sampling strategies. Plant Dis. 92: 401-408.

Kandel, H. 2012. 2011 National Sunflower Association survey. Proc. 34th Annu. Sunflower Res. Forum. National Sunflower Association, Bismarck, ND. Online publication. http://www.sunflowernsa.com/uploads/resources/616/2011-sunflowersurvey-kandel.pdf

Kolmer, J. A. 1999. Virulence dynamics, phenotypic diversity, and virulence complexity in two populations of Puccinia triticina in Canada from 1987 to 1997. Can. J. Bot. 77:333-338.

Kolmer, J. A., and Liu, J. Q. 2000. Virulence and molecular polymorphism in international collections of the wheat leaf fungus Puccinia triticina. Phytopathology 90:427-436.

Kong, G., Coulter, K., Kochman, J., and Thompson, S. 1999. Evolution of pathotypes of Puccinia helianthi on sunflower in Australia. Australas. Plant Pathol. 28:320-332.

Markell, S., Gulya, T., McKay, K., Hutter, M., Hollingsworth, C., Ulstad, V., Koch, R., and Knudsvig, A. 2009. Widespread occurrence of the aecial stage of sunflower rust caused by Puccinia helianthi in North Dakota and Minnesota in 2008. Plant Dis. 93:668.

Markell, S. G., and Milus, E. A. 2008. Emergence of a novel population of Puccinia striiformis f. sp. tritici in eastern United States. Phytopathology 98: 632-639.

Miller, J. F., Rodriguez, R. H., and Gulya, T. J. 1988. Evaluation of genetic materials for inheritance of resistance to Race 4 rust in sunflower. Pages 361365 in: Proc. $12^{\text {th }}$ Int. Sunflower Conf., International Sunflower Association, Paris.

Moreno, P. S., de Romano, A. B., Romano, M. C., Vergani, P., Sposaro, M., Bulos, M., Altieri, E., Ramos, M. L., and Sala, C. A. 2011. A survey of physiological races of Puccinia helianthi in Argentina. In: Proc. 18th Int. Sunflower Conf. Mar del Plata, Argentina. Online publication. http://www.asagir.org. ar/asagir2008/buscar_congreso.asp?

Putt, E. D., and Sackston, W. E. 1957. Studies on sunflower rust I. Some sources of rust resistance. Can. J. Plant Sci. 37:43-54.

Putt, E. D., and Sackston, W. E. 1963. Studies on sunflower rust IV. Two genes, $\mathrm{R}_{1}$ and $\mathrm{R}_{2}$ for resistance in the host. Can. J. Plant Sci. 43:490-496.

Qi, L. L., Gulya, T., Seiler, G. J., Hulke, B. S., and Vick, B. A. 2011. Identification of resistance to new virulent races of rust in sunflowers and validation of DNA markers in the gene pool. Phytopathology 101:241-249.

Qi, L. L., Seiler, G. J., Vick, B. A., and Gulya, T. J. 2012. Genetics and mapping of the $R_{11}$ gene conferring resistance to recently emerged rust races, tightly linked to male fertility restoration, in sunflower (Helianthus annuus L.). Theor. Appl Genet. 125:921-932.

Sendall, B. C., Kong, G. A., Goulter, K. C., Aitken, E. A. B., Thompson, S. M., Mitchell, J. H. M., Kochman, J. K., Lawson, W., Shatte, T., and Gulya, T. J. 2006. Diversity in the sunflower: Puccinia helianthi pathosystem in Australia. Australas. Plant Pathol. 35:657-670.

Yang, S. M., Antonelli, E. F., Luciano, A., and Luciani, N. D. 1986. Reactions of Argentine and Australian sunflower rust differentials to four North American cultures of Puccinia helianthi from North Dakota. Plant Dis. 70:883-886.

Yang, S. M., Dowler, W. M., and Luciano, A. 1989. Gene $\mathrm{Pu}_{6}$ : A new gene in sunflower for resistance to Puccinia helianthi. Phytopathology 79 474-477. 